\title{
Scripps’s Murrelet at San Miguel Island, California: status of a small population at the northwest limit of the breeding range
}

\author{
Darrell L. Whitworth ${ }^{1}{ }^{*}$ and Harry R. Carter ${ }^{1,2, \dagger}$ \\ ${ }^{1}$ California Institute of Environmental Studies, Box 1185, Davis, CA 95617 \\ ${ }^{2}$ Humboldt State University, Department of Wildlife, 1 Harpst Street, Arcata, CA 95521
}

\begin{abstract}
Aвstract.-San Miguel Island (SMI) and its adjacent islets, Prince Island and Castle Rock, support a small population of Scripps's Murrelets (Synthliboramphus scrippsi) at the northwest limit of their breeding range. In 1994-1996, 2004, 2007, and 2015, we conducted at-sea surveys and nest searches to determine the breeding distribution and population size of the Scripps's Murrelet at the SMI group. During at-sea vocal surveys in 1994-1996, murrelet calls were heard at 4 stations around Prince Island (43-167 calls), 2 stations off Castle Rock (6 calls and 80 calls), and 4 stations off northeast SMI (5-123 calls), but none were detected at 8 stations off southern and northwestern SMI. At-sea spotlight surveys in 2004, 2007, and 2015 confirmed murrelet congregations off Prince Island and northeast SMI. Annual mean $( \pm$ SD) spotlight counts on a standard transect off of northeast SMI and Prince Island were $9 \pm 0$ murrelets $(n=2)$ in 2004, $19 \pm 4$ $(n=3)$ in 2007, and $91 \pm 15(n=2)$ in 2015; much higher spotlight counts at Prince Island accounted for the higher mean in 2015. We found murrelet nests in 4 of the 12 areas searched at SMI and Prince Island. In 2007 the first murrelet nests ever found on SMI proper were discovered at Harris Point, Bay Point, and Hoffman Point in isolated shoreline habitats that were inaccessible to endemic Island Foxes (Urocyon littoralis littoralis) but accessible to nonnative Black Rats (Rattus rattus). Using spotlight counts we estimated 100-263 breeding pairs at the SMI group in 2015, mainly at Prince Island (90\%) where foxes and rats were absent. Spotlight surveys have not been conducted at Castle Rock, but $<5$ pairs were suspected. Introducing rats from SMI proper to the offshore islets is the most serious threat to murrelets at this remote island, although a large oil spill could also extirpate this population. Spotlight surveys and nest searches should be conducted at least every 5 years to confirm persistence of this vulnerable species at SMI and to detect major changes in population size.
\end{abstract}

Resumen.—La isla San Miguel (SMI, por sus siglas en inglés) y sus islotes adyacentes (Prince Island y Castle Rock) alojan a una pequeña población de mérgulos de Scripps (Synthliboramphus scrippsi) en el límite noroeste de su rango de reproducción. En los años 1994-1996, 2004, 2007 y 2015, realizamos muestreos en el mar y búsquedas de nidos para determinar la distribución de los sitios de reproducción y el tamaño poblacional de los mérgulos de Scripps, en la Isla San Miguel y sus islotes. Durante evaluaciones vocales en el mar en 1994-1996, se escucharon llamados de mérgulos en 4 sitios alrededor de Prince Island (43-167 llamados), en 2 sitios en Castle Rock (entre 6 y 80 llamados) y en 4 sitios al noreste de la Isla San Miguel (5-123 llamados), pero no se detectaron en 8 sitios del sur y del noroeste de la Isla San Miguel. Los muestreos en el mar en 2004, 2007 y 2015 confirmaron agrupaciones de mérgulos en Prince Island y en el noreste de la Isla San Miguel. El promedio anual $( \pm$ SD) de conteo de individuos en los transectos al noreste de la Isla San Miguel y de Prince Island fue de $9 \pm 0$ mérgulos $(n=2)$ en 2004, $19 \pm 4(n=3)$ en 2007 y de $91 \pm 15(n=2)$ en 2015. El promedio más alto del conteo de mérgulos en Prince Island, ocurrió en 2015. Encontramos nidos de mérgulos en 4 de las 12 áreas evaluadas en la Isla San Miguel y en Prince Island. En 2007, encontramos los primeros nidos de mérgulos en la Isla San Miguel, descubiertos en Harris Point, Bay Point y Hoffman Point en hábitats costeros aislados, inaccesibles para el zorro isleño endémico (Urocyon littoralis littoralis) pero accesibles para las ratas negras no nativas (Rattus rattus). En 2015, utilizando el método de conteo, estimamos entre 100-263 parejas reproductoras en la Isla San Miguel y sus islotes, principalmente en Prince Island (90\%) donde no se encontraron zorros ni ratas. No llevamos a cabo un muestreo en Castle Rock, pero sospechamos sobre la presencia de $<5$ parejas. La introducción de ratas provenientes de la Isla San Miguel a los islotes representa la amenaza más seria para los mérgulos en esta isla remota, aunque grandes derrames de petróleo también podrían aniquilar a esta población. Los muestreos que se enfocan en conteos y búsquedas de nidos deberían realizarse al menos cada 5 años para confirmar la persistencia de esta especie vulnerable en la Isla San Miguel y para detectar cambios importantes en el tamaño poblacional.

*Corresponding author: darrellwhitworth@ciesresearch.org $\dagger$ Deceased 
San Miguel Island (SMI) is the northwesternmost of the 12 known Scripps's Murrelet (Synthliboramphus scrippsi) breeding islands off southern California, USA, and northwest Baja California, Mexico (Drost and Lewis 1995, Carter et al. 2005, Birt et al. 2012). SMI and its adjacent islets, Prince Island and Castle Rock, support one of the smallest Scripps's Murrelet populations in the world, but little information is available concerning the history, distribution, and population trends of murrelets at this remote island. Given this murrelet's restricted breeding range and small world population size (7000-8000 breeding pairs; Karnovsky et al. 2005), improved knowledge of murrelet distribution and trends at SMI is critical to the long-term conservation efforts for this species, which is listed as threatened in California (Burkett et al. 2003) and vulnerable by the International Union for Conservation of Nature (IUCN 2017).

Relying solely on colony-based studies to assess colony size, population trends, or even the presence of Scripps's Murrelets is not possible at most islands because murrelet nests are usually concealed in rocky crevices located in rugged, steep, and often inaccessible coastal habitats (Murray et al. 1983, Whitworth et al. $2005,2013)$, especially on islands where terrestrial mammalian predators are present (McChesney and Tershy 1998, Whitworth et al. 2014, 2018). Thus, despite palaeontological evidence that has established the presence of murrelets at SMI for several thousand years (Guthrie 1980, 1992, Collins et al. 2005), naturalists did not detect murrelets during infrequent visits between 1875 and 1927 (Henshaw 1876, Streator 1887, 1888, Willett 1910, 1912, Wright and Snyder 1913, Howell 1917, Grinnell and Miller 1944, Hunt et al. 1979; Appendix 1). Clearly the rugged, remote murrelet breeding habitats at SMI had greatly hindered efforts to detect this secretive species. In fact, murrelets were not reported at SMI (at sea near Prince Island) until 1939, and the first direct evidence of breeding was not discovered until murrelet eggs and breeding adults were found on Prince Island and Castle Rock in 1968 (Appendix 1). Surveys in 1975-1977 (Hunt et al. 1979) and 1991 (Carter et al. 1992) confirmed breeding on Prince Island, but no nests were found on SMI.

Since 1994 the development of at-sea survey techniques examining murrelet activity in nocturnal congregations (Whitworth et al. 1997, Hamilton et al. 2011) adjacent to coastal breed- ing areas has greatly facilitated assessments of colony size and population trends (Whitworth and Carter 2014, 2018, Whitworth et al. 2014, 2018). In 1994-1996 we used vocal surveys of murrelets attending at-sea congregations (Whitworth et al. 2014) to determine the rough distribution and relative size of breeding colonies on SMI, Prince Island, and Castle Rock and to examine temporal variability in vocal activity at Prince Island. In 2004, 2007, and 2015, we used spotlight surveys (Whitworth and Carter $2014,2018)$ to count murrelets attending atsea congregations at SMI and Prince Island; our 2 main goals were (1) to establish baseline data for long-term population monitoring and (2) to obtain reliable data for a standardized population estimate. During the studies in 1994-1996, 2007, and 2015 we also searched for nests on SMI and Prince Island. In this paper we summarize the status and distribution of Scripps's Murrelets at SMI, Prince Island, and Castle Rock during our intermittent survey efforts in 1994-2015.

\section{Methods \\ Study Area}

SMI $\left(34^{\circ} 02^{\prime} \mathrm{N}, 120^{\circ} 22^{\prime} \mathrm{W}\right)$ is a relatively small low-lying island ( -3375 ha; maximum elevation $253 \mathrm{~m}$ ) located off the coast of southern California about $40 \mathrm{~km}$ south of Point Conception (Fig. 1). The SMI group including Prince Island ( $\sim 13$ ha; $90 \mathrm{~m})$, Castle Rock (4 ha; $55 \mathrm{~m}$ ), and several smaller offshore rocks is the westernmost of the 4 northern Channel Islands, an island chain formed by the western extension of the Santa Monica Mountain Range after it enters the Pacific Ocean west of Los Angeles. SMI has a relatively cool, coastal Mediterranean climate moderated by frequent periods of dense fog. The island lies outside the protection of Point Conception and is regularly buffeted by strong northwest winds and large swells. The periphery of SMI proper is mainly composed of sandy beaches topped by low bluffs, but steep slopes and cliffs are found near Harris Point and Bay Point. SMI is owned by the U.S. Navy which comanages the island with Channel Islands National Park. The island is uninhabited, but housing and a small campground are maintained for rangers, maintenance staff, researchers, and visitors.

The SMI group supports the largest and most diverse assemblage of breeding seabirds 


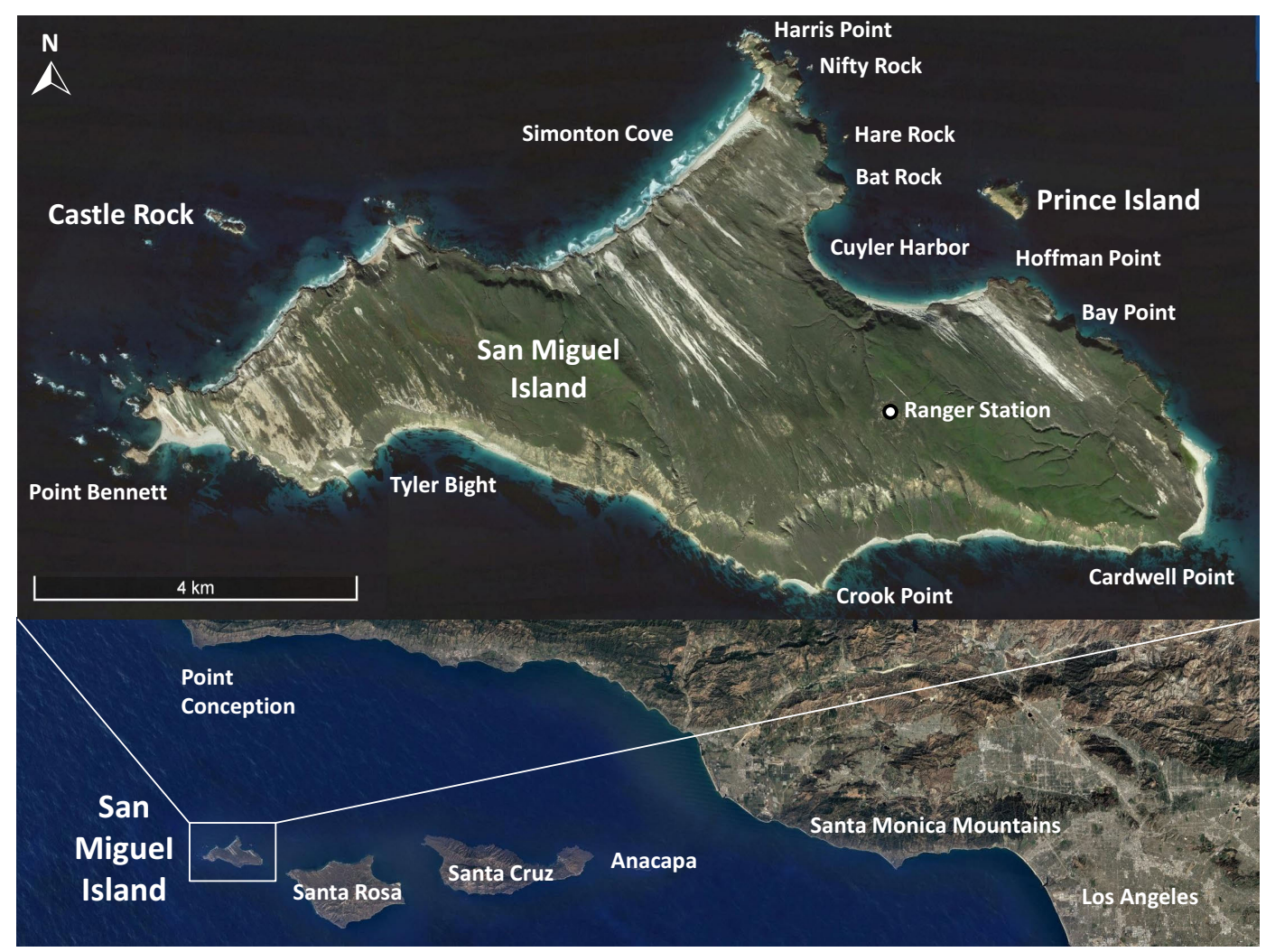

Fig. 1. San Miguel Island, California, with Prince Island, Castle Rock, and other locations mentioned in the text labeled. Lower inset shows the location of San Miguel Island among the 4 northern Channel Islands off the coast of southern California.

(up to 14 species) in the California Channel Islands (Carter et al. 1992). However, endemic Island Foxes (Urocyon littoralis littoralis) and nonnative Black Rats (Rattus rattus) prevent seabirds from breeding over much of SMI proper; thus, most seabirds breed on Prince Island and Castle Rock which are both free of terrestrial predators. Relatively large and regionally important colonies of Cassin's Auklets (Ptychoramphus aleuticus) and Ashy StormPetrels (Oceanodroma homochroa) occur on Prince Island (Carter et al. 1992). Tufted Puffins (Fratercula cirrhata), Common Murres (Uria aalge), and Rhinoceros Auklets (Cerorhinca monocerata) also breed irregularly at the SMI group, which is the southern breeding limit for all 3 of these species (McChesney et al. 1995).

\section{Vocal Surveys}

Vocal surveys were used to count the number of murrelet "twitter" calls heard within a 15-min survey period conducted (1) from a land-based station on the southeast shore of Prince Island hourly through the night (beginning as early as 9:00 PM [Pacific Standard Time; i.e., 21:00] and ending as late as 6:00 $\mathrm{AM}$ [i.e., 06:00]) and (2) from a 4-m inflatable boat at 18 at-sea stations located 100-200 m from shore off SMI, Prince Island, and Castle Rock (Fig. 2). The observer counted all calls separated by at least $3 \mathrm{~s}$ from the previous call emanating from the same direction and relative distance. Detailed survey techniques are provided in Whitworth et al. (2014). Vocal survey dates are provided in Table 1. Each of the 18 at-sea vocal survey stations was surveyed only once.

\section{Nocturnal Spotlight Surveys}

We conducted nocturnal spotlight surveys on GPS transects located 150-300 m from shore off SMI and Prince Island (Figs. 2, 3). The observer used a handheld spotlight to count all murrelets observed in a $180^{\circ}$ arc off 


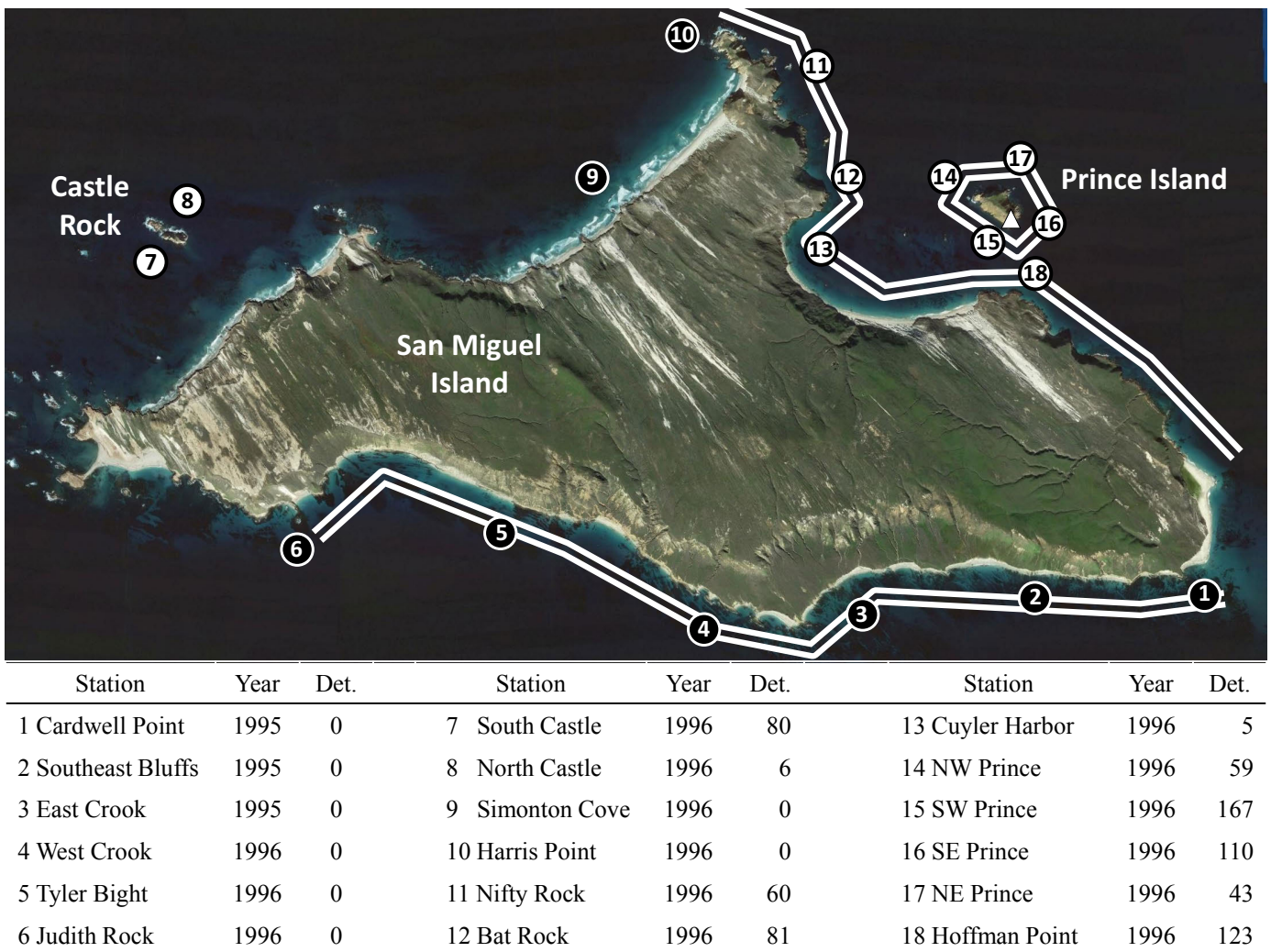

Fig. 2. Scripps’s Murrelet vocal survey stations (numbered circles) and spotlight survey transects (double lines) at San Miguel Island, California. Numbered circles correspond to at-sea vocal survey stations listed in the inset table which includes the station number, name, survey year, and number of calls detected (Det.). Black circles indicate stations where no calls were recorded. The white triangle on Prince Island indicates the location of the land-based station.

TABLE 1. Summary of Scripps's Murrelet vocal surveys, spotlight surveys, and nest search efforts at San Miguel Island (SMI), California, in 1994-1996, 2004, 2007, and 2015. See Figs. 2-4 for locations of the survey areas.

\begin{tabular}{|c|c|c|}
\hline Survey & Location ( $n=$ no. of surveys/searches) & Dates \\
\hline \multirow[t]{2}{*}{ Vocal } & SE Prince Island $(n=38)$ & 8, 11, and 12 Apr 1994; 4 May 1995 \\
\hline & At-sea stations $(n=18)$ & 4 May 1995; 28 Apr 1996 \\
\hline \multirow[t]{3}{*}{ Spotlight } & Northeast SMI $(n=7)$ & $\begin{array}{l}29 \text { Mar, } 26 \text { May } 2004 ; 1,2 \text {, and } 22 \text { May } 2007 \text {, } \\
16 \text { Apr } 2015(2)\end{array}$ \\
\hline & Bay Point-Cardwell Point $(n=4)$ & 29 Mar $2004 ; 1,2$, and 22 May 2007 \\
\hline & Tyler Bight-Cardwell Point $(n=1)$ & 26 Apr 2004 \\
\hline \multirow[t]{12}{*}{ Nest } & SE Prince Island $(n=3)$ & 11 Apr 1994; 29 Apr 1996; 16 Apr 2015 \\
\hline & SW Prince Island ${ }^{\mathrm{a}}(n=1)$ & $16 \mathrm{Apr}^{\mathrm{a}} 2015$ \\
\hline & East Prince Island $(n=1)$ & 24 Apr 2007 \\
\hline & North Cliffs Prince Island $(n=1)$ & 7 Aug 1994 \\
\hline & West Harris Point $(n=1)$ & 1 May 2007 \\
\hline & East Harris Point ${ }^{\mathrm{a}}(n=3)$ & 12 Jul 1994; 1 and 22 Maya 2007 \\
\hline & Nifty Rock $(n=1)$ & 23 Apr 2007 \\
\hline & Hare Rock $(n=4)$ & 11 Apr, 12 Jul 1994; 4 May 1995; 23 Apr 2007 \\
\hline & Rhino Cave $(n=6)$ & $\begin{array}{l}5 \text { May, } 12 \text { Jul 1994; } 4 \text { May 1995; } 23 \text { Apr, } \\
1 \text { and } 22 \text { May } 2007\end{array}$ \\
\hline & North Cuyler Harbor $(n=1)$ & 29 Apr 1996 \\
\hline & Hoffman Point ${ }^{\mathrm{a}}(n=4)$ & $24 \mathrm{Apr}^{\mathrm{a}}, 2$ and 22 May 2007; $16 \mathrm{Apr}^{\mathrm{b}} 2015$ \\
\hline & Bay Point ${ }^{\mathrm{a}}(n=2)$ & 2 and 22 Maya $^{2} 007$ \\
\hline
\end{tabular}

Evidence of Scripps's Murrelet nesting was discovered.

bPartial survey. 


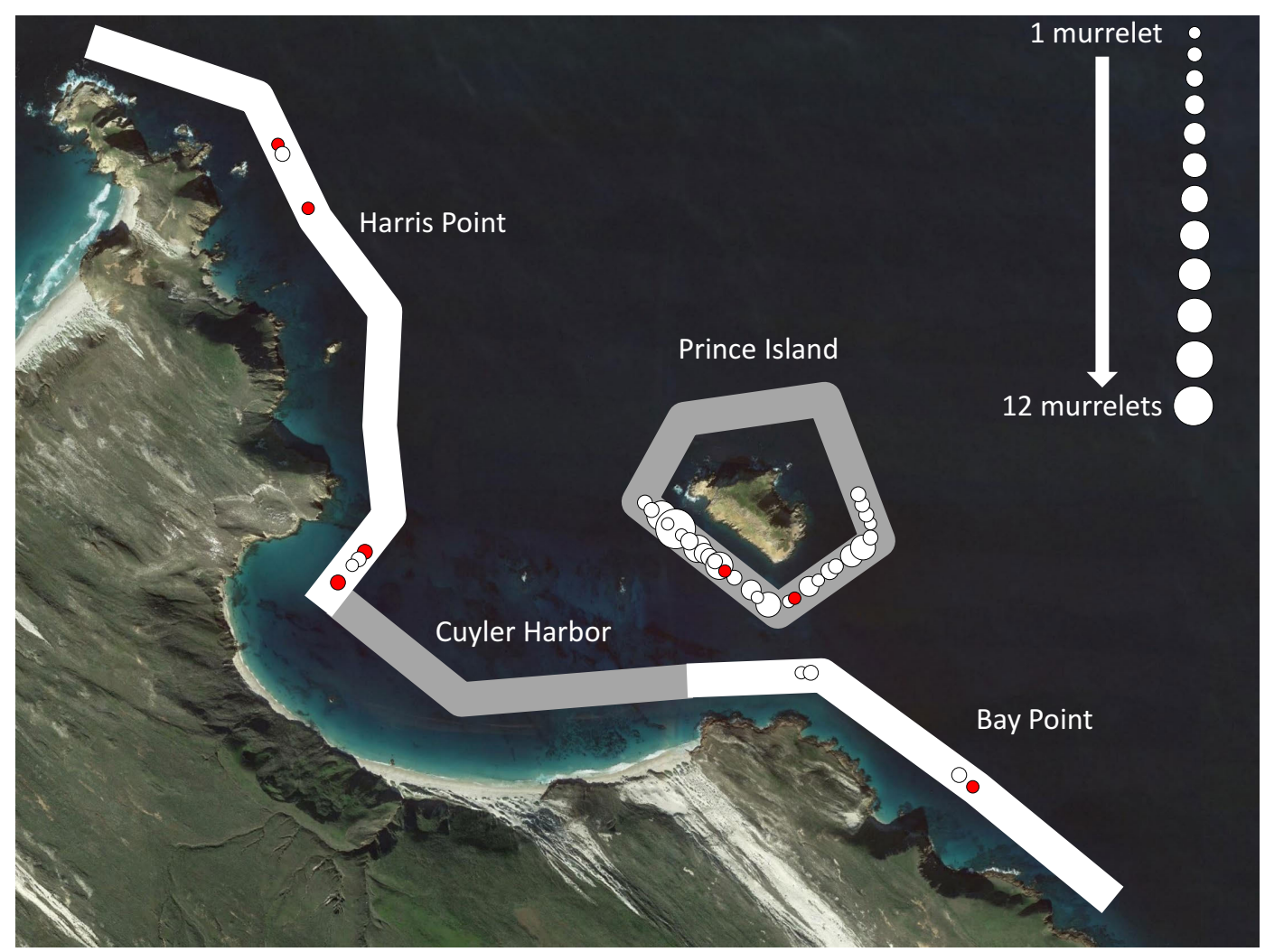

Fig. 3. Transect legs for the standardized Scripps's Murrelet spotlight surveys at San Miguel Island, California, in 2004, 2007, and 2015. Scaled circles illustrate the distribution of murrelets during spotlight surveys on 26 May 2004 (red circles) and 16 April 2015 (white circles).

the bow of the survey vessel. Detailed spotlight survey methods are provided in Whitworth and Carter (2014). Spotlight survey dates and locations are provided in Table 1. Surveys in 2004 and 2007 were conducted from a 4-m inflatable boat; surveys in 2015 were conducted from the bow of the 15-m research vessel Alguita.

We combined the contiguous Harris Point $(\sim 3.7 \mathrm{~km})$, Cuyler Harbor $(\sim 2.0 \mathrm{~km})$, and Bay Point $(\sim 2.4 \mathrm{~km})$ transect segments with the subsequent Prince Island transect $(\sim 3.2 \mathrm{~km})$ to create a standardized northeast SMI survey (Fig. 3) for comparisons between years. The northeast SMI standard transect $(\sim 11.3 \mathrm{~km})$ sampled all known breeding areas at the SMI group except Castle Rock. Attempts to conduct spotlight surveys at Castle Rock and along the northwest shore of SMI in 2004 and 2007 were abandoned due to strong winds and large swells.

\section{Nest Searches}

Nest searches were conducted in 12 discrete areas on SMI and Prince Island: (1) 4 areas on Prince Island, (2) 4 areas on Harris Point between Simonton Cove and Cuyler Harbor, (3) Nifty Rock, (4) Hare Rock, (5) Hoffman Point, and (6) Bay Point (Table 1, Fig. 4). We used small handheld flashlights to search suitable crevices for evidence of breeding (e.g., incubating or brooding adults, unattended eggs, broken or hatched eggs and membranes; Whitworth et al. 2005, 2013). The date(s) of nest searches in each area are provided in Table 1. Except for Castle Rock, we believe all boat-accessible murrelet breeding habitats were searched at least once in 1994-2015, but we could not search some potential breeding habitats in inaccessible, high cliffs at Bay Point, Prince Island, and near Bat Rock (Fig. 4). We did not search on Castle Rock to avoid disturbing large numbers 


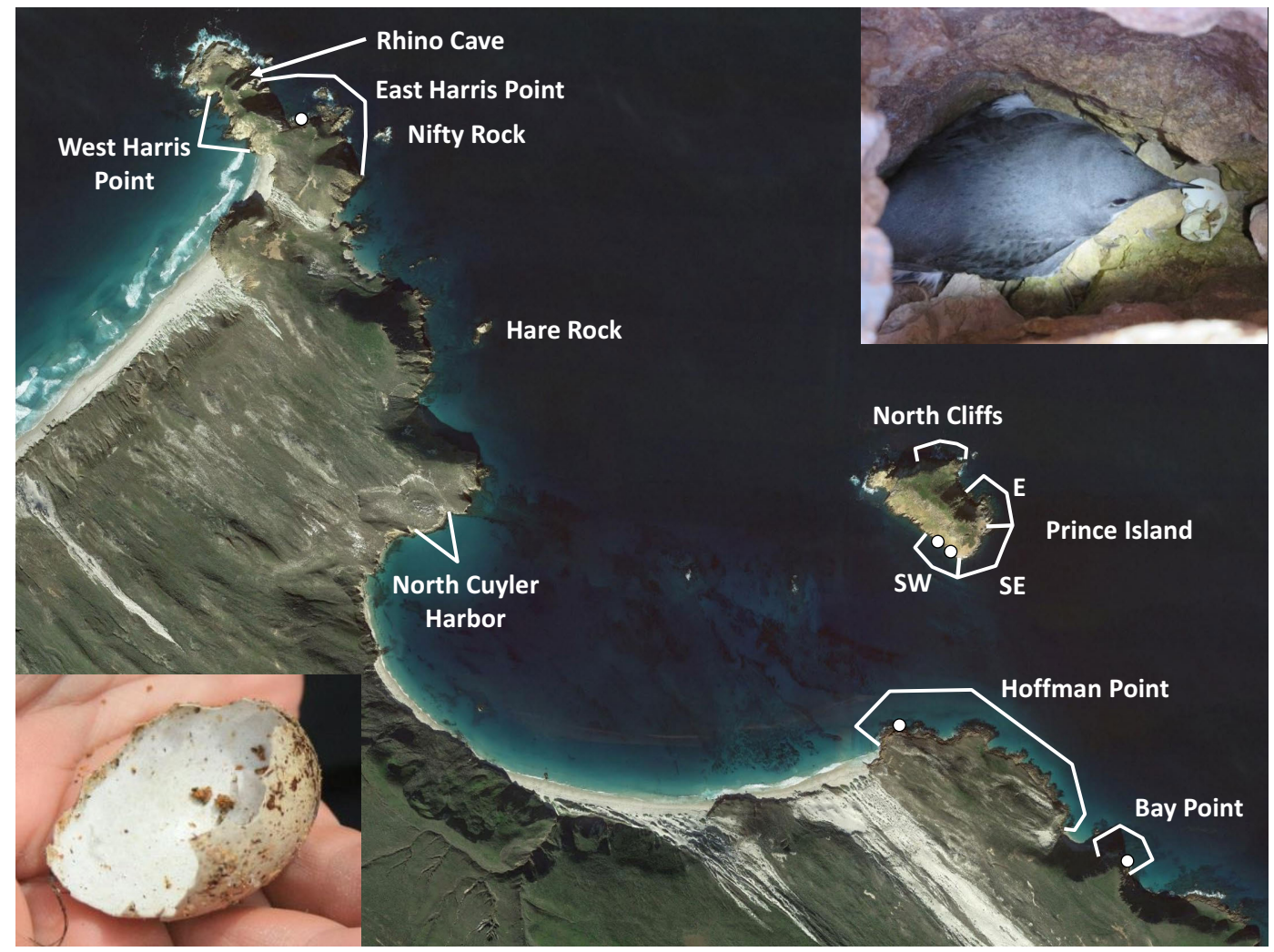

Fig. 4. Areas searched for Scripps's Murrelet nests at San Miguel Island, California, in 1994-1996, 2007, and 2015. Insets show an adult murrelet brooding chicks on Prince Island on 16 April 2015 (upper right) and a depredated murrelet egg found at Hoffman Point on 24 April 2007 (lower left). White circles indicate the locations of murrelet nests.

of breeding Brandt's Cormorants (Phalacrocorax penicillatus), Northern Fur Seals (Callorhinus ursinus), and California Sea Lions (Zalophus californianus).

\section{RESULTS}

\section{Vocal Surveys}

LAND-BASED SURVEYS.-Total calls detected per 15-min survey ranged from 0 to 42 (14 \pm $10[\bar{x} \pm \mathrm{SD}])$ during 38 land-based vocal surveys over 4 nights on Prince Island in 1994-1995 (Fig. 5). In 1994 nightly means were $15 \pm 13$ calls (range $0-37, n=9$ ) on 8 April, $12 \pm 8$ calls (range $0-26, n=10$ ) on 11 April, and 13 \pm 12 calls (range $0-42, n=10$ ) on 12 April. On 4 May 1995 the nightly mean was $15 \pm 6$ calls (range $8-24, n=9$ ). Maximum calls were recorded at midnight on 8 April 1994, 02:00 on 11 April 1994, and 05:00 on 12 April 1994 and 4 May 1995. No consistent nightly trends were noted (Fig. 5). Murrelets began calling by 21:00 or 22:00 each night, and calls were invariably heard through the night after vocalizing began, although only 1 call was recorded at 01:00 h on 11 April 1994, just 1 hour before that night's maximum (26 calls) at 02:00

AT-SEA SURVEYS.-Survey totals ranged from 0 to 167 calls at 18 at-sea stations in 1995-1996 (Fig. 2). Vocal activity was concentrated at Prince Island, Castle Rock, and the northeast shore of SMI from Nifty Rock to Hoffman Point. No calls were recorded at 6 stations off south SMI or at single stations in Simonton Cove and off the north tip of Harris Point.

\section{Spotlight Surveys}

Scripps's Murrelets were observed around Prince Island, between Harris Point and north Cuyler Harbor, and between Hoffman Point and Bay Point. Murrelets were not observed in Cuyler Harbor or off south SMI. Replicate counts on the northeast SMI transect were greater in 2015 than in 2004 and 

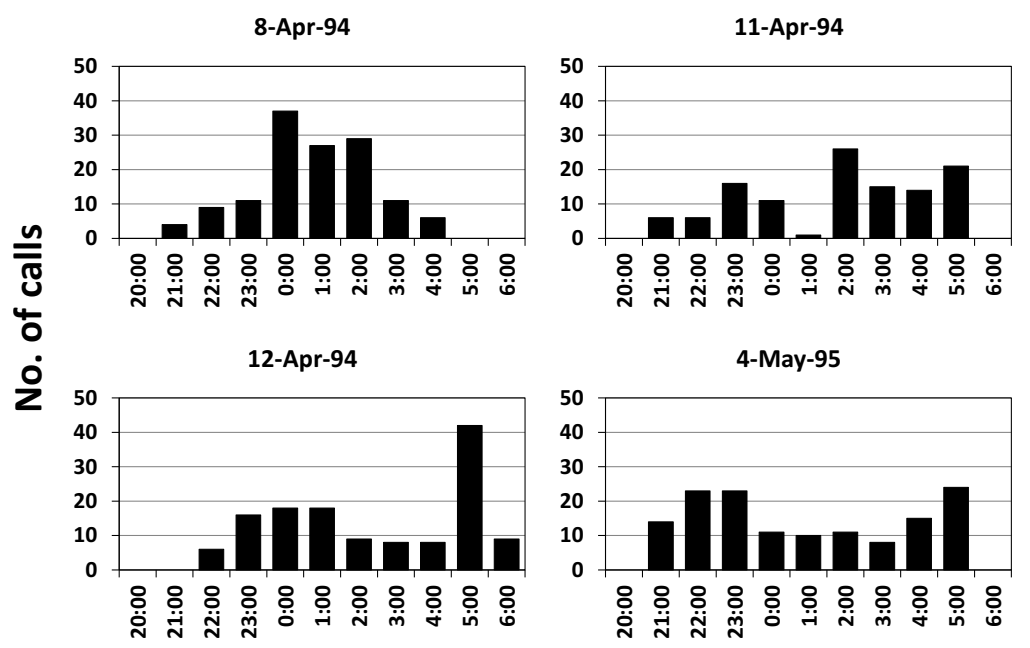

Time

Fig. 5. Number of Scripps's Murrelet calls heard during vocal surveys on the southeast shore of Prince Island in $1994-1995$.

Table 2. Number of Scripps's Murrelets counted on each leg of the standardized northeast San Miguel Island spotlight surveys conducted in 2004, 2007, and 2015. Percentages indicate the proportion of the total survey count.

\begin{tabular}{|c|c|c|c|c|c|c|}
\hline \multirow[b]{2}{*}{ Year } & \multirow[b]{2}{*}{ Date } & \multicolumn{4}{|c|}{ Transect leg } & \multirow[b]{2}{*}{ Total } \\
\hline & & Harris Point & Cuyler Harbor & Bay Point & Prince Island & \\
\hline \multirow[t]{2}{*}{2004} & $29 \mathrm{Mar}$ & $5(56 \%)$ & 0 & 0 & $4(44 \%)$ & 9 \\
\hline & 26 May & $6(66 \%)$ & 0 & $1(11 \%)$ & $2(22 \%)$ & 9 \\
\hline \multirow[t]{3}{*}{2007} & 1 May & $13(59 \%)$ & 0 & $1(5 \%)$ & $8(36 \%)$ & 22 \\
\hline & 2 May & $17(74 \%)$ & 0 & $1(4 \%)$ & $5(22 \%)$ & 23 \\
\hline & 22 May & $5(38 \%)$ & 0 & $7(54 \%)$ & $1(8 \%)$ & 13 \\
\hline \multirow{2}{*}{2015} & $16 \mathrm{Apr}$ & $5(5 \%)$ & 0 & $5(5 \%)$ & $96(91 \%)$ & 106 \\
\hline & $16 \mathrm{Apr}$ & $3(4 \%)$ & 0 & 0 & $73(96 \%)$ & 76 \\
\hline
\end{tabular}

2007 (Table 2). In 2004 the mean spotlight count was quite low $(9 \pm 0 ; n=2)$, in 2007 it more than doubled $(19 \pm 4 ; n=3)$, then in 2015 it increased again more than 4 -fold $(91 \pm 15 ; n=$ 2). Mean counts for the Prince Island transect were lowest in $2004(3 \pm 1)$, slightly higher in 2007 (5 \pm 3 ), then much higher in 2015 (85 \pm 12). In contrast, means were consistently low in all years on the Harris Point transect $(6 \pm 1$ in 2004; $12 \pm 5$ in 2007; $4 \pm 1$ in 2015) and the Bay Point transect ( $1 \pm 1$ in 2004; $3 \pm 3$ in both 2007 and 2015). The observer was about $1 \mathrm{~m}$ higher on the Alguita in 2015 compared to the inflatable boat in 2004 and 2007 , but we do not believe that this difference affected counts (Whitworth and Carter 2014).

Murrelet distribution was generally consistent among northeast SMI surveys. Murrelets were seen on the Prince Island and Harris Point legs during all 7 northeast SMI surveys and on the Bay Point leg during 5 of 7 surveys (Table 2). However, the proportions of murrelets counted on each leg varied considerably. The Harris Point leg accounted for more than half of all murrelets $(56 \%-74 \%)$ counted during 4 of 5 replicate surveys in 2004 and 2007. In contrast, Prince Island accounted for almost all murrelets (91\%-96\%) counted during surveys in 2015.

\section{Nest Searches}

We found evidence of murrelet breeding in 4 of the 12 areas searched on SMI and Prince Island (Table 1, Fig. 4). On SMI proper in 2007, abandoned eggs were found at East Harris Point and depredated eggs were found at Hoffman Point and Bay Point (Fig. 4). On Prince Island in 2015, incubating and brooding adult murrelets (Fig. 4) were found in separate 
crevices on the southwest shoreline. No evidence of murrelet breeding was found in the other 8 areas, although other seabird species were found breeding in some areas (Appendix 2). Murrelet nests found at East Harris Point, Bay Point, and Hoffman Point in 2007 represented the first direct evidence of murrelet nesting ever found on SMI proper. The broken egg at Hoffman Point was found in a rock crevice about $10 \mathrm{~m}$ above the shoreline, the 2 abandoned eggs at East Harris Point were found in a shallow crevice on a low sheer northfacing ledge, and the rat-depredated eggs at Bay Point were found in a shoreline cave. The nests on SW Prince Island containing 1 adult incubating eggs and 1 adult brooding chicks were found in crevices $2-3 \mathrm{~m}$ above the high tide line.

\section{Discussion}

\section{Scripps's Murrelet Population Size at SMI}

Spotlight surveys of Scripps's Murrelets in at-sea congregations have greatly improved our knowledge of the population size and distribution of this vulnerable species at SMI and Prince Island. Early studies by the Pacific Ocean Biological Survey Program in 1968 and the University of California, Irvine (UCI), in 1975-1977 provided the earliest murrelet population estimates for the SMI group, but these estimates were based primarily on nonstandardized data, including (1) small numbers of nests found on Prince Island, (2) murrelet calls heard at Prince Island and SMI, and (3) murrelets captured on or near Prince Island and Castle Rock (Appendix 1). In 1968 the Pacific Ocean Biological Survey Program estimated $45 \pm 5$ individuals, which we treated as 20-25 pairs, although this number probably represented only Prince Island because evidence of breeding was not noted at SMI and only 1 murrelet was captured at Castle Rock. Less than 10 years later, UCI estimated "approximately 75 pairs" mainly on Prince Island (Hunt et al. 1979:167), although they noted vocalizing and suspected nesting on SMI. Hunt et al. (1979:165) stated that "it seems likely that a small number find refuge from the resident foxes in the rocky cliff areas from Bat Rock to Harris Point and possibly in a limited area east of Cuyler Harbor" (i.e., Hoffman and Bay Points) and suspected that it was "likely a small population persists" on
Castle Rock. In 1991 Humboldt State University recorded extensive vocal activity at Prince Island and found 2 nests there after the breeding season (Appendix 1) but did not consider these data sufficient to improve upon the UCI estimate (Carter et al. 1992).

Vocal surveys in 1994-1996 confirmed the presence of murrelet congregations off Prince Island, northeast SMI, and Castle Rock. We compared the numbers of calls heard at the 18 SMI at-sea stations with similar surveys at Santa Barbara Island, California, where population size was roughly known on portions of the island (Carter et al. 1992), and we thereby broadly estimated 50-300 pairs at the SMI group in 1994-1996 (Burkett et al. 2003). This estimate included 5-25 pairs at Castle Rock, 30-100 pairs at Prince Island, 10-150 pairs at Harris Point, and 5-25 pairs at the Bay Point/ Hoffman Point area. The wide range of the 1995-1996 population estimate reflected the difficulties of interpreting vocal survey data, including (1) the poorly known relationship between vocal activity and numbers nesting on the adjacent shoreline, (2) highly variable vocal activity through the night (Fig. 5), and (3) single surveys at widely spaced stations (Fig. 2).

Spotlight surveys in 2004 and 2007 confirmed the distribution of murrelets demonstrated by vocal surveys in 1994-1996, but the unexpectedly low spotlight counts in both years (range 9-23 murrelets) were not consistent with our impression of colony size based on the earlier vocal surveys and raised concerns about a potential decline in this small murrelet population since 1996. Spotlight counts in 2015 were more than 4 times greater than in 2007 and alleviated concerns about population decline. However, with only 1-3 nights of surveys conducted each year in 2004, 2007, and 2015 , it was unclear whether higher counts in 2015 reflected an actual population increase. Lower mean spotlight counts in 2004 and 2007 may have resulted from (1) simple sampling biases in the small annual survey samples and (2) differences in the timing of surveys each year (Table 2 ) exacerbated by relatively late and poor murrelet breeding in the northern Channel Islands in 2004 (Whitworth et al. 2013).

Using spotlight counts in 2015, we estimated 100-263 murrelet pairs at SMI and Prince Island. To obtain this population estimate, we used a correction factor (95\% CI 1.10-2.89 nests/murrelet) determined at northeast Santa 
Barbara Island that quantified the relationship between the mean number of murrelets counted on a standard spotlight transect and concurrent nest counts on the adjacent shoreline (D. Whitworth unpublished data). The rather wide range of the population estimate and correction factor reflects the urgent need for (1) larger survey samples at SMI to ensure that representative mean spotlight counts are obtained for estimating population size and (2) more studies to better assess the relationship between at-sea congregations and murrelet breeding at Santa Barbara Island, which appears to be the only murrelet breeding island where a reliable correction factor can be safely determined. We considered 100-263 pairs at SMI and Prince Island in 2015 to be the best available population estimate until larger samples of spotlight surveys are conducted at SMI, Prince Island, and Castle Rock. Our estimate includes all known breeding areas at the SMI group except Castle Rock, which was not surveyed in 2004-2015. Vocal surveys indicated that murrelets nested at Castle Rock as recently as 1996, but we suspect $<5$ nests based on the small amount of suitable crevice habitat noted during a complete search of the islet in October 1991 (Carter et al. 1992).

Assessing murrelet population trends at SMI over the period 1968-2015 is not possible because it is unclear whether the differences in the population estimates for 1968 (20-25 pairs), 1975-1977 (75 pairs), 1994-1996 (50-300 pairs), and 2015 (100-263 pairs) reflected actual changes in the number of murrelets over this period or rather differences in the survey techniques used to obtain these estimates. Periodic natural fluctuations in this small population are certainly possible and might be expected at the northern limit of the species' breeding range but would be difficult to detect with the varied survey techniques and infrequent survey efforts at SMI since 1968. Important anthropogenic factors may have also affected the population in some years. In 1968 the collection of 11 breeding adults ( $\sim 25 \%$ of the estimated breeding population at the time), 1 subadult, and 1 chick at Prince Island may have had prolonged effects on the small colony through adult mortality and reduced hatching success. The following year, the catastrophic 1969 Santa Barbara oil spill extended to SMI in February-May and probably caused mortality at all murrelet colonies in the northern Channel Islands, especially of birds congregating beside breeding areas at night (Carter et al. 2000, Carter 2003).

Foxes, Rats, and Murrelet

Breeding Distribution at SMI

As at Santa Catalina Island and San Clemente Island, California (Whitworth et al. 2014, 2018), the chief long-term breeding constraint for murrelets at SMI appears to be the availability of suitable crevice sites in coastal habitats that are inaccessible to Island Foxes (Hunt et al. 1979, McChesney and Tershy 1998). Foxes have been present on SMI since the northern Channel Islands were isolated from the California mainland 16,500 years ago (Wayne et al. 1991); thus, murrelets have probably never bred in fox-accessible habitats on SMI. The SMI fox population numbered about 400 individuals in 2011 (Coonan et al. 2014), but we suspect that foxes currently have little direct effect on murrelets because foxes probably cannot (or do not) access steep slope, cliff, and sea cave breeding habitats at Harris Point, Hoffman Point, and Bay Point; murrelets also do not breed in fox-accessible habitats above sandy beaches and low bluffs at Cuyler Harbor, Simonton Cove, and south SMI. Surveys were not conducted around Point Bennett due to dangerous surf and low offshore rocks, but murrelets likely do not breed there because the shoreline is accessible to foxes, contains little or no crevice habitat (based on nest searches in 1991; Carter et al. 1992), and is covered by marine mammals for much of the year.

Unlike foxes, Black Rats alone do not appear to completely exclude murrelets from suitable breeding habitats, especially those habitats that may be visited only occasionally by rats. Evidence of rats (including rat-depredated eggs) has been found in murrelet breeding areas at SMI, Santa Catalina Island, San Clemente Island, and-prior to rat eradication in 2002-Anacapa Island, and hatching success appeared to be greatly reduced in these areas (Whitworth et al. 2005, 2013, 2014, 2018, Jones et al. 2005). In 2007 ratdepredated eggs at Hoffman Point and Bay Point provided the first direct evidence of murrelet breeding and rat impacts on SMI (Fig. 4). We also found abundant evidence of rats (e.g., feces and food caches) in seabird breeding areas near Harris Point, most notably 
in and around Rhino Cave (Fig. 4). Rats are a relatively recent addition to the SMI fauna, first noted in the 1970s but probably introduced many decades before via shipwreck (4 shipwrecks occurred between 1905 and 1923) or sheep ranching (Collins 1979, Roberts 1991). For several decades after the introduction of rats, foxes apparently restricted rats to shoreline habitats on the west and north sides of SMI (Collins 1979, Erickson and Halvorson 1990, McChesney and Tershy 1998). Rats became more widespread in the late 1990s and early 2000s following a major decline in fox numbers in 1994-1999 due to predation by Golden Eagles (Aquila chrysaetos) (Coonan et al. 2005). A fox restoration program resulted in a rapid recovery to predecline levels by 2011 (Coonan et al. 2014), which presumably has reduced or eliminated rats in at least some of the areas that rats had colonized during the fox population decline.

\section{Murrelet Breeding on Prince Island}

Prince Island clearly supports most of the murrelets currently breeding at the SMI group, largely because this offshore islet provides a refuge from foxes and rats. Nest monitoring has not been conducted on Prince Island, but hatching success is probably much higher than on SMI. The few murrelet nests found on Prince Island in 1968-2015 contained mainly hatched eggshells and incubating or brooding adults (Appendix 1), including (1) 1 adult brooding chicks and 1 incubating adult in April 2015, (2) 1 incubating adult in an artificial Cassin's Auklet nest in June 2008, (3) a hatched eggshell in an artificial nest in August 2007, (4) 1 brooding adult in May 1999, (5) 4 "active" nests (likely with incubating adults) in March 1977, (6) 1 incubating adult in May 1975, and (7) a departing chick in June 1968. Clutch fates were not known for 6 "broken" eggshells reported on Prince Island in May-June 1968 and several inactive nests found in May 1975 although, based on the observation dates, we suspect that many chicks had probably hatched. A subspecies of deer mouse (Peromyscus maniculatus streatori) endemic to the SMI group is the only terrestrial egg predator (Schwemm and Martin 2005) present on Prince Island (von Bloeker 1967, Pergams and Ashley 2000). Even though mice are widespread in seabird nesting areas on the south side of Prince Island, mouse-depre- dated eggs have not yet been reported. In fact, only 1 failed clutch has ever been documented at Prince Island: an abandoned egg found in an artificial Cassin's Auklet nest in June 2008 (Appendix 1).

Competition for nest sites may be the primary factor limiting murrelet breeding on Prince Island. The islet has abundant rock crevices and soil for burrowing that permit widespread breeding by thousands of Cassin's Auklets (mainly in burrows, but also in crevices), while hundreds of Pigeon Guillemots (Cepphus columba) and in some years small numbers of Tufted Puffins nest in crevices on the north cliffs (Hunt et al. 1979, Carter et al. 1992, McChesney et al. 1995). Competition among Cassin's Auklets for crevices on Prince Island may be intense, as suggested by high occupancy rates in artificial nest sites since 1986 (Channel Islands National Park and J. Adams unpublished data). Cassin's Auklets and Pigeon Guillemots have both been known to oust murrelets from crevices on Anacapa Island (Whitworth et al. 2013), so they may also limit murrelet nesting opportunities on Prince Island. Hunt et al. (1979:165, 167) stated that murrelets "may be outcompeted for nest space by the ubiquitous Cassin's Auklet on Prince Island" and went on to state that "during the breeding season, auklets crowded into almost every crack and crevice typically used for Xantus's [Scripps's] Murrelet nest sites at other locations in the Bight." Similarly, Cassin's Auklets occupied nearly every suitable crevice on the south and southeast shore of Prince Island in April 1994 and April 2015. Some murrelet nests on SMI may result from birds hatched on Prince Island that struggled to find unoccupied crevices on the islet and therefore attempted to breed in nearby habitats on SMI.

\section{Restoration Concepts}

Breeding conditions for murrelets on Anacapa Island greatly improved following the eradication of rats (Whitworth et al. 2005, 2013, Whitworth and Carter 2018), but a similar effort on SMI is complicated by the presence of the Island Fox which is a threatened species in California but was removed from the endangered species list by the U.S. Fish and Wildlife Service in 2016 (USFWS 2016). While rat eradication on SMI has been considered (MSRP 2005), the potential negative impacts on the recently recovered fox 
population were deemed too risky to attempt even small-scale rodent control measures (e.g., predator-proof fences around murrelet breeding areas). Given the proximity of Prince Island $(740 \mathrm{~m})$ and Castle Rock $(990 \mathrm{~m})$ to SMI, the introduction of rats would pose tremendous risks to murrelets and other seabirds breeding on these important islet refuges. Biosecurity measures including surveillance programs to detect rats on Prince Island and Castle Rock should be implemented as soon as possible to prevent extensive damage to murrelets in the event that an introduction occurs. Surveillance programs on Castle Rock would need to be conducted in the fall to avoid disturbing breeding seabirds and marine mammals.

Habitat restoration on Prince Island is needed to repair damage from past guano harvesting and military bombing. Seabird breeding habitats were severely impacted by the removal of large amounts of guano from Prince Island between 1895 and 1916 (Doran 1980). The loss of burrow and crevice breeding habitats may also have resulted from explosions on Prince Island and SMI. The SMI group became a U.S. Navy bombing range in 1948; portions of SMI and Prince Island were used for aerial bombing practice in 1950-1953 and missile testing from the late 1950s to the early 1970s (Roberts 1991, Roberti 2008). In the 1950s D. Bleitz visited Prince Island after a bombing exercise and noted that the island top had been "cindered." Artificial nesting habitat could be installed to replace lost crevice- and burrow-nesting habitat for Scripps's Murrelet, Cassin's Auklet, and Ashy Storm-Petrel. More work is needed to assess the damage from past impacts and to devise methods for large-scale deployments.

\section{Future Monitoring}

Annual population monitoring of Scripps's Murrelets at SMI, Prince Island, and Castle Rock is probably not feasible given the remote location and the difficult ocean conditions during the murrelet breeding season. However, periodic monitoring is needed to detect major changes in population size and possible impacts from rats. We suggest that monitoring at SMI is best accomplished with a combination of spotlight surveys and nest monitoring which together would provide the most reliable data on the status of the murrelet population. We do not consider vocal surveys adequate for population monitoring due to the great temporal variation in vocal activity and the difficulties of interpreting the relationship between vocal activity and colony size. Nightly variation in spotlight counts at Anacapa, Santa Catalina, and San Clemente Islands (Whitworth and Carter 2014, 2018, Whitworth et al. 2014, 2018) indicated that 8-10 nights during the peak breeding season are desirable in order to obtain representative baseline data for assessing population size and trends. Smaller survey samples may be adequate at SMI because the small murrelet colony likely has less variation within and between years. Reduced survey efforts (4-6 nights) may still be difficult in most years at SMI due to frequent windy conditions at night and high costs of working at this remote island. Similarly, locating an adequate sample of 10-20 nests to obtain reliable estimates of hatching success and timing of breeding at Prince Island and SMI may not be feasible because only 5 murrelet nests were found during nest searches in 2007 and 2015 combined. We suggest that a realistic approach for detecting major population changes at SMI would be to conduct (1) 4-5 nights of spotlight surveys at northeast SMI and Prince Island in late March to late April every 3-4 years (avoiding major El Niño years when breeding may be reduced) and (2) nest searches and monitoring on Prince Island and SMI in the same years as spotlight surveys. For this approach, baseline data will still need to be gathered because survey efforts in 2004, 2007, and 2015 were not adequate for this purpose but were useful for roughly estimating population size, examining breeding distribution, and establishing a standardized transect for future spotlight surveys. At a minimum, nest searches and 1-2 nights of spotlight surveys should be conducted every 5 years to confirm that this small Scripps's Murrelet population persists, which was a key finding of our intermittent surveys in 1994-2015.

\section{ACKNOWLEDGMENTS}

Surveys in 2015 were conducted by the California Institute of Environmental Studies (CIES) with funding from the National Fish and Wildlife Foundation (S. Hall; Project 45760). In-kind support was provided by Channel Islands National Park and Montrose Settlements Trustee Council, with assistance 
from D. Mazurkiewicz and I. Williams. The California Institute of Environmental Studies (F. Gress and J. Brenner) provided field equipment and administrative support. Vessel support was provided by the Algalita Marine Research Foundation (ORV Alguita; captains C. Moore and D. Selvam). Surveys were assisted by M. Parker and D. Mazurkiewicz.

Surveys in 2007 were conducted by Carter Biological Consulting and CIES with funding from Montrose Settlements Trustee Council through the U.S. Fish and Wildlife Service (Order 801817M091) and assistance from A. Little, J. Boyce, and K. Faulkner. In-kind support was provided by Channel Islands National Marine Sanctuary (CINMS; C. Mobley). Vessel support was provided by Ocean Sports Private Charters (Miss Devin; captain R. Fairbanks and crew F. Orsua) and CINMS (R/V Shearwater; captains L. Moody, T. Shinn, C. Lara, and K. Peet). Surveys were assisted by J. Koepke and P. Hébert.

Surveys in 2004 were conducted by CIES with funding from a U.S. Fish and Wildlife Service Section 6 grant through the California Department of Fish and Wildlife (E. Burkett). Administrative and logistic support was provided by CIES, CINMS (S. Fangman and C. Mobley), and Channel Islands National Park (K. Faulkner and P. Martin). Vessel support was provided by CINMS $(\mathrm{R} / \mathrm{V}$ Shearwater; captains L. Moody, T. Shinn, and C. Lara). Surveys were assisted by J. Koepke, S. Fangman, D. Carlson, and P. Rubechini.

Surveys in 1994-1996 were conducted by Humboldt State University with funding from the U.S. Navy (Legacy Resources Management Program), U.S. Fish and Wildlife Service, and California Department of Fish and Wildlife, with assistance from T. Keeney, T. Zimmerman, and E. Burkett. In-kind support was provided by the U.S. Navy (T. Keeney), National Biological Service (D. Gilmer), and Humboldt State University (R. Golightly). Vessel support was provided by Instinct Charters (F/V Instinct; captain D. Christy and crew B. Christy). Surveys were assisted by G. McChesney, W. McIver, L. Ochikubo, M. Pierson, and J. Bulger.

\section{Literature Cited}

Birt, T.P., H.R. Carter, D.L. Whitworth, A. MCDonald, S.H. Newman, F. Gress, E. Palacios, J.S. KoepKe, AND V.L. Friesen. 2012. Rangewide population structure of the Xantus's Murrelet (Synthliboramphus hypoleucus). Auk 129:44-55.

Burkett, E.E., N.A. Rojek, A.E. Henry, M.J. Fluharty, L. Comrack, P.R. Kelly, A.C. Mahaney, and K.M. FIEN. 2003. Status review of Xantus's Murrelet (Synthliboramphus hypoleucus) in California. California Department of Fish and Game, Habitat Conservation Planning Branch, Status Report 2003-01, Sacramento, CA.

Carter, H.R. 2003. Oil and California's seabirds: an overview. Marine Ornithology 31:1-7.

Carter, H.R., G.J. MCChesney, D.L. Jaques, C.S. Strong, M.W. Parker, J.E. Takekawa, D.L. Jory, AND D.L. Whitworth. 1992. Breeding populations of seabirds in California, 1989-1991. Volume 1, Population estimates. Unpublished draft report, U.S. Fish and Wildlife Service, Northern Prairie Wildlife Research Center, Dixon, CA.

Carter, H.R., S.G. Sealy, E.E. Burkett, and J.F. Piatt. 2005. Biology and conservation of the Xantus's Murrelet: discovery, taxonomy, and distribution. Marine Ornithology 33:81-87.

Carter, H.R., D.L. Whitworth, J.Y. Takekawa, T.W. Keeney, And P.W. Kelly. 2000. At-sea threats to Xantus' Murrelets (Synthliboramphus hypoleucus) in the Southern California Bight. Pages 435-447 in D. Browne, H. Chaney, and K. Mitchell, editors, 5th Channel Islands Symposium. Minerals Management Service, Camarillo, CA.

Collins, P.W. 1979. Vertebrate zoology: the biology of introduced black rats on Anacapa and San Miguel Islands. Pages 14.1-14.49 in D.M. Power, editor, Natural resources study of the Channel Islands National Monument, California. Santa Barbara Museum of Natural History, Santa Barbara, CA.

Collins, P.W., D.A. Guthrie, T.C. Rick, and J.M. ErLandson. 2005. Analysis of prey remains excavated from an historic Bald Eagle nest site on San Miguel Island, California. Pages 103-120 in D.K. Garcelon and C.A. Schwemm, editors, Proceedings of the 6th California Islands Symposium. National Park Service Technical Publication CHIS-05-01, Institute for Wildlife Studies, Arcata, CA.

Coonan, T.J., V. Bakker, B. Hudgens, C.L. Boser, D.K. GarCELON, AND S.A. Morrison. 2014. On the fast track to recovery: island foxes on the northern Channel Islands. Monographs of the Western North American Naturalist 7:373-381.

Coonan, T.J., C.A. Schwemm, G.W. Roemer, D.K. Garcelon, and L. Munson. 2005. Decline of an island fox subspecies to near extinction. Southwestern Naturalist 50:32-41.

Doran, A.L. 1980. Pieces of eight Channel Islands: a bibliographic guide and source book. Arthur H. Clark Company, Glendale, CA. 340 pp.

Drost, C.A., and D.B. Lewis. 1995. Xantus' Murrelet (Synthliboramphus hypoleucus). In: A. Poole and F. Gill, editors, The Birds of North America No. 164. Academy of Natural Sciences, Philadelphia, PA, and American Ornithologists' Union, Washington, DC.

ERICKSON, W.A., AND W.L. HaLvorson. 1990. Ecology and control of the roof rat (Rattus rattus) in Channel Islands National Park. Unpublished report, University of California, Cooperative National Park Resources Study Unit, Technical Report No. 38, Davis, CA.

Grinnell, J., AND A.H. Miller. 1944. The distribution of the birds of California. Pacific Coast Avifauna 27. 
Guthrie, D.A. 1980. Analysis of avifaunal and bat remains from midden sites on San Miguel Island. Pages 689-702 in D.M. Power, editor, The California Islands: proceedings of a multidisciplinary symposium. Santa Barbara Museum of Natural History, Santa Barbara, CA.

Guthrie, D.A. 1992. A late Pleistocene avifauna from San Miguel Island, California. Pages 319-327 in K.E. Campbell Jr., editor, Papers in Avian Paleontology Honoring Pierce Brodkorb. Natural History Museum of Los Angeles County Scholarly Series 36.

Hamilton, C.D., R.T. Golightly, and J.Y. Takekawa. 2011. Relationships between breeding status, socialcongregation attendance and foraging distance of Xantus's Murrelets. Condor 113:140-149.

Henshaw, H.W. 1876. Appendix H8. Report on the ornithology of the portions of California visited during the field-season of 1875. Pages 224-278 in G.M. Wheeler, editor, Annual report upon the geographical surveys west of the One Hundredth Meridian in California, Nevada, Utah, Colorado, Wyoming, New Mexico, Arizona, and Montana: being Appendix JJ of the annual report of the Chief of Engineers for 1876. Government Printing Office, Washington, DC.

Howell, A.B. 1917. Birds of the islands off the coast of southern California. Pacific Coast Avifauna 12.

Hunt, G.L., Jr., R.L. Pitman, M. Naughton, K. Winnett, A. Newman, P.R. Kelly, and K.T. Briggs. 1979. Distribution, status, reproductive biology and foraging habits of breeding seabirds. Pages 1-399 in Summary of marine mammals and seabird surveys of the Southern California Bight area, 1975-1978. Volume 3. Investigator's reports, Part 3: Seabirds of the Southern California Bight, Book 2. Unpublished report, University of California, Irvine, CA.

[IUCN] INTERNATIONAL UNION FOR CONSERVATION OF NATURE. 2017. The IUCN Red List of Threatened Species. Version 2017-1. www.iucnredlist.org

Jones, H.P., R.W. Henry III, G.R. Howald, B.R. Tershy, AND D.A. Croll. 2005. Predation of artificial Xantus's Murrelet (Synthliboramphus hypoleucus) nests before and after black rat (Rattus rattus) eradication. Environmental Conservation 32:320-325.

Karnovsky, N.J., L.B. Spear, H.R. Carter, D.G. Ainley, K.D. AmeY, L.T. Ballance, K.T. Briggs, R.G. Ford, G.L. Hunt JR., C. Keiper, Et AL. 2005. At-sea distribution, abundance and habitat affinities of Xantus's Murrelets. Marine Ornithology 33:89-104.

McChesney, G.J., H.R. Carter and D.L. Whitworth. 1995. Reoccupation and extension of southern breeding limits of Tufted Puffins and Rhinoceros Auklets in California. Colonial Waterbirds 18:79-90.

McChesney, G.J., And B.R. Tershy. 1998. History and status of introduced mammals and impacts to breeding seabirds on the California Channel Islands and Northwestern Baja California Islands. Colonial Waterbirds 21:335-347.

[MSRP] Montrose Settlements Restoration ProGRAM. 2005. Final restoration plan and programmatic environmental impact statement, and environmental impact report. Report of the Montrose Settlements Restoration Program. National Oceanic and Atmospheric Administration, U.S. Fish and Wildlife Service, National Park Service, California Department of Fish and Game, California Department of Parks and Recreation, and California State Lands Commission.
Murray, K.G., K. Winnett-Murray, Z.A. Eppley, G.L. HunT JR., AND D.B. SCHWARTZ. 1983. Breeding biology of the Xantus' Murrelet. Condor 85:12-21.

Pergams, O.R.W., and M.V. Ashley. 2000. California island deer mice: genetics, morphometrics, and evolution. Pages 278-288 in D. Browne, H. Chaney, and K. Mitchell, editors, 5th Channel Islands Symposium. Minerals Management Service, Camarillo, CA.

Roberti, B.L. 2008. San Miguel Island: my childhood memoir 1930-1942. Santa Cruz Island Foundation, Occasional Paper No. 10, Santa Barbara, CA. 130 pp.

Roberts, L.J. 1991. San Miguel Island: Santa Barbara's fourth island west. Cal Rim Books, Carmel, CA.

Schwemm, C.A., And P.L. Martin. 2005. Effects of egg predation by native rodents on nesting Xantus's Murrelets (Synthliboramphus hypoleucus), Santa Barbara Island, California. Pages 385-394 in D.K. Garcelon and C.A. Schwemm, editors, Proceedings of the 6th California Islands Symposium. National Park Service Technical Publication CHIS-05-01, Institute for Wildlife Studies, Arcata, CA.

Streator, C.P. 1887. The water birds of San Miguel Island. Santa Barbara Society of Natural History Bulletin 1:21-23.

Streator, C.P. 1888. Notes of the birds of the Santa Barbara Islands. Ornithologist and Oologist 13:52-54.

[USFWS] United States Fish and Wildlife Service. 2016. Endangered and threatened wildlife and plants; removing the San Miguel island fox, Santa Rosa island fox, and Santa Cruz island fox from the federal list of endangered and threatened wildlife, and reclassifying the Santa Catalina island fox from endangered to threatened. Federal Register 81(156): 53315-53333.

VON BLOEKER, J.C., JR. 1967. Land mammals of the southern California islands. Pages 245-263 in R.N. Philbrick, editor, Proceedings of the Symposium on the Biology of the California Islands. Santa Barbara Botanic Garden, Santa Barbara, CA.

Wayne, R.K., S.B. George, D. Gilbert, P.W. Collins, S. Kovach, D. Girman, And N. Lehman. 1991. A morphologic and genetic study of the island fox, Urocyon littoralis. Evolution 45:1849-1868.

Whitworth, D.L., and H.R. Carter. 2014. Nocturnal spotlight surveys for monitoring Scripps's Murrelets in at-sea congregations at Anacapa Island, California. Monographs of the Western North American Naturalist 7:306-320.

Whitworth, D.L., And H.R. Carter. 2018. Population trends for Scripps's Murrelets following eradication of black rats. Journal of Wildlife Management 82:232-237.

Whitworth, D.L., H.R. Carter, T.M. Dvorak, L.S. FarLEY, AND J. KING. 2014. Status, distribution, and conservation of the Scripps's Murrelet at Santa Catalina Island, California. Monographs of the Western North American Naturalist 7:321-338.

Whitworth, D.L., H.R. Carter, and F. Gress. 2013. Recovery of a threatened seabird after eradication of an introduced predator: eight years of progress for the Scripps's Murrelet at Anacapa Island, California. Biological Conservation 162:52-59.

Whitworth, D.L., H.R. Carter, M.W. Parker, F. Gress, AND M. BOOKER. 2018. Long-term monitoring of Scripps's Murrelet and Guadalupe Murrelet at San Clemente Island, California: evaluation of baseline 
data in 2012-2016. Western North American Naturalist 78:457-473.

Whitworth, D.L., H.R. Carter, R.J. Young, J.S. Koepke, F. Gress, and S. Fangman. 2005. Initial recovery of Xantus's Murrelets following rat eradication on Anacapa Island, California. Marine Ornithology 33: 131-137.

Whitworth, D.L., J.Y. TakeKawa, H.R. Carter, and W.R. MCIvER. 1997. Night-lighting as an at-sea capture technique for Xantus' Murrelets in the Southern California Bight. Colonial Waterbirds 20: $525-531$.

Appendix 1. Observations of Scripps's Murrelets at Prince Island, Castle Rock, and San Miguel Island, California, 1927-1991.

\section{Prince Island (PI)}

1927.-PI was visited on 31 March by D.S. DeGroot, J.R. Pemberton, and H.W. Carringer (see Pemberton 1928, Hunt et al. 1979). DeGroot (unpublished field notes) reported, "At the north end of the island, found a small colony of auklets [Cassin's Auklet] and Bill [Pemberton] and I dug out a few. Also smelled murrelets [Scripps's Murrelet; SCMU] in holes in the rocks nearer the water. Saw no birds tho."

1939.- Sumner and Bond (1939, p. 29) reported, "A single individual [SCMU] was seen at a distance of a few yards, about a quarter of a mile north of Prince Island." This observation occurred on 17 or 18 April 1939.

1968. - No mention of SCMU or nesting during a visit to PI (18:00-23:00) on 15 May (Crossin and Brownell 1968). Between 28 May and 7 June, 6 "broken eggshells" were found, and 12 adults (USNM 544885-544887，54889-54997; 11 with brood patches and 1 without brood patches) and 1 chick (USNM 544888) were collected on the rocky east and southeast slopes (Huber 1968). It is not clear if the "broken eggshells" had hatched but, based on the observation dates, we suspect many or all had hatched. Roughly $45 \pm 5$ individuals were estimated. J.T. Lewis (personal communication) confirmed that no nests were found at PI in 1968.

1975.-PI was visited on 13 May. Hunt et al. (1979) reported 1 nest and a "high count" (i.e., defined as "the greatest number of birds captured on or near the island on any one night") of 25 murrelets. However, Briggs et al. (1978) reported that 1 active nest and several inactive nests were found. In addition, 5 birds flew aboard the boat and approximately 25 birds were heard flying around the island. R.L. Pitman (personal communication) confirmed that SCMU attracted to deck lights were captured on a boat anchored off PI.

1976._PI was visited monthly in Mar-Jun 1976. Ten SCMU were banded but no nests were found (Hunt et al. 1979). More details were found in
Willett, G. 1910. A summer trip to the northern Santa Barbara Islands. Condor 12:170-174.

Willett, G. 1912. Birds of the Pacific slope of southern California. Pacific Coast Avifauna 7.

Wright, H., AND G.K. SNyder. 1913. Birds observed in the summer of 1912 among the Santa Barbara Islands. Condor 15:86-92.

Received 22 February 2017

Revised 3 October 2017

Accepted 12 January 2018

Published online 9 October 2018

unpublished 1976 field notes of R.L. Pitman and S.M. Speich. Single nights were spent at PI for mist-net captures, banding, food sample collections, and nest counts. The support boat usually moved from PI before dark to anchor overnight at Cuyler Harbor, except for 17-18 March and 6-7 April (see below).

17-18 March: The boat was anchored off PI (17:30-06:30). SCMU calls were not noted, although many Cassin's Auklets were attracted to the deck lights and flew aboard.

6-7 April: Many SCMU were calling in the early evening (19:45-21:30) and one bird (with brood patches) was captured onboard while the boat was anchored off PI. At 21:30, the boat moved from PI to anchor in Cuyler Harbor.

28-29 April: During island night work, 5 SCMU without brood patches were banded (1143-84350 to 1143-84354), including one pair in a crevice, but no eggs were found.

29-30 April: During island work, one bird (1063-87586; with refeathering brood patches) was banded of 2 pairs examined.

20-21 May: During island night work, 2 SCMU captured on rocks at the south end were banded (812-70507, 812-70508).

21-22 May: None recorded.

8-9 June: During island night work, SCMU were heard calling but none were observed on the island.

1977.- Two SCMU were collected 5 miles N of Harris Point on 15 February 1977 by S. Speich and G.L. Hunt Jr. (LACM 88020, 90223). PI was visited monthly from March through June. Four nests were found, 8 birds were banded, and a "high count" of 60 birds occurred on 20 March (Hunt et al. 1979). Based on 1975 information (above), we suspect that the high count of 60 birds indicated a rough estimate of the number of SCMU calling at night. Overall, 75 pairs of SCMU were estimated at the SMI group in 1975-1977 (Hunt et al. 1979, pages 167, 251). Field notes for 1977 were not located. Hunt et al. (1979) noted that all nests were found "along the southeast portion of the island and were especially concentrated in an area of rocky outcroppings at the north end of the Opuntia patch on this side of the island." 
1991._-Carter et al. (1992, unpublished data) did not find any nests during the breeding season, but searches were not conducted near the Opuntia patch (see above) to avoid disturbing nesting Double-crested Cormorants (Phalacrocorax auritus). During a whole-island burrow and crevice count at PI on 22-23 October, one crevice with a SCMU eggshell fragment was found at the southeast end and one crevice with a possible murrelet eggshell fragment was found at the north end.

SCMU called from the water and were seen flying over the southeast end during storm-petrel mist-netting. Vocalizing was greater in April than in June; almost all were gone by July. Details each night are as follows:

4-5 April: Mist net open from 21:16 to 01:00. SCMU vocalizations (1-2 birds at a time) noted every 5-10 minutes from $21: 16$ to $22: 30$ and then less often until the mist net was closed.

5-6 April: Mist net open from 19:44 to 00:04. SCMU vocalizations (1-3 birds at a time) noted every 10-30 minutes; the first call was noted at 19:13. At 22:16 and 22:58, single birds flew over the mist net.

7-8 June: Mist net open from $\sim 21: 00$ to 04:45. SCMU vocalizations (1-2 birds at a time) noted infrequently from 21:35 to 04:45.

9-10 July: Mist net open from 21:20 to 03:40. SCMU noted vocalizing once at $\sim 22: 00$.

8-9 July, 10-11 July, 12-13 July, and 13-14 July: SCMU not heard during mist-netting.

\section{Castle Rock (CR)}

1968.-An adult SCMU with bare brood patches (USNM 544041) but without eggs or chicks was collected from a rock crevice on the night of 14 May (Crossin and Brownell 1968). J.T. Lewis (personal communication) confirmed that no nests were found at CR.

1976. - No evidence of nesting was found during burrow and crevice nest searches on 8 June and 24 June (Hunt et al. 1979; R.L. Pitman unpublished field notes).

1977.- No evidence of nesting was found during a brief landing on 4 June (Hunt et al. 1979).

1991.-No evidence of nesting was obtained on a whole-island burrow and crevice count at CR on 21-22 October (Carter et al. 1992).

\section{San Miguel Island (SMI)}

1968.-Hare Rock was searched on 15 May but no SCMU or other nesting seabirds were recorded (Crossin and Brownell 1968). Between 28 May and 7 June, no studies were conducted on SMI because the U.S. Navy would not give permission for access (J.T. Lewis personal communication). Huber (1968) noted that breeding SCMU at SMI were nearly impossible to detect, but they may breed in certain areas, such as the rock slope directly south of PI (i.e., Hoffman Point Area).
1976. - In the breeding season, SCMU calls were heard in Cuyler Harbor and a few flew aboard a boat at anchor (Hunt et al. 1979). On 21-22 May, murrelet calls were heard on the water near a rocky cliff just north of Cuyler Harbor, most likely Bat Rock. Hunt et al. (1979) noted that breeding may occur on SMI between Bat Rock and Harris Point and in a limited area east of Cuyler Harbor, probably Hoffman Point. On 25 June, Hare Rock was searched but no evidence of nesting was found (R.L. Pitman unpublished field notes).

1977.- - In the breeding season, SCMU were heard calling in Cuyler Harbor and a few flew aboard a boat at anchor (Hunt et al. 1979).

1991.-No evidence of SCMU was found at Hare Rock on 11 May and 7 June, or south of Bat Rock on 11 May (Carter et al. 1992).

\section{ACKNOWLEDGMENTS}

Historical information was collated from the literature and the following unpublished sources: (1) field notes obtained from the 1991 HSU seabird survey in the Channel Islands and archived at the USFWS, San Francisco Bay National Wildlife Refuge; (2) information on Scripps's Murrelet nests found at Prince Island in 1998-2015 provided by Josh Adams (U.S. Geological Survey) and Aaron Hebshi (Point Blue Conservation Science); (3) copies of reports (Crossin and Brownell 1968, Huber 1968) prepared by the Pacific Ocean Biological Survey and obtained by Gerard J. McChesney (HSU) from the Smithsonian Institution, with assistance from Roger Clapp; (4) copies of field notes and trip reports for surveys in 1975-1977 provided by Steve Speich; (5) helpful information provided by Robert L. Pitman and James T. Lewis about past surveys in 1968 and 1975-1977; and (6) field notes of D.S. DeGroot obtained from the Western Foundation of Vertebrate Zoology.

\section{Literature Cited}

Briggs, K.T., H.L. Jones, G.L. Hunt Jr., D.B. Lewis, W.B. Tyler, and E.W. Chu. 1978. Distribution, numbers and population movements. Pages 473-651 in Marine mammal and seabird surveys of the Southern California Bight area. Volume 3. Principal Investigator's Reports, Book 2, Seabirds. Unpublished report, University of California, Santa Cruz, CA.

Carter, H.R., G.J. McChesney, D.L. Jaques, C.S. Strong, M.W. Parker, J.E. Takekawa, D.L. Jory, AND D.L. WhitworTh. 1992. Breeding populations of seabirds in California, 1989-1991. Volume 1, Population estimates. Unpublished draft report, U.S. Fish and Wildlife Service, Northern Prairie Wildlife Research Center, Dixon, CA.

Crossin, R.S., and R.L. Brownell. 1968. Preliminary report of Channel Islands survey. Eastern Area Cruse No. 41. Unpublished manuscript, Smithsonian Institution, Washington, DC. 
Huber, L.N. 1968. Preliminary report of San Miguel Island and adjacent islets, Prince and Castle. Unpublished manuscript, Smithsonian Institution, Washington, DC.

Hunt, G.L., Jr., R.L. Pitman, M. Naughton, K. Winnett, A. Newman, P.R. Kelly, and K.T. Briggs. 1979. Distribution, status, reproductive biology and foraging habits of breeding seabirds. Pages 1-399 in Summary of marine mammals and seabird surveys of the Southern California Bight area, 1975-1978. Vol-

ApPENDIX 2. Scripps's Murrelet nest searches and nests found at Prince Island, Castle Rock, and San Miguel Island, California, in 1994-2015. Observations by Humboldt State University (1994-1996), California Institute for Environmental Studies (2007, 2015), or others as noted.

\section{Prince Island (PI)}

1994.-On 11-12 April, no Scripps's Murrelet (SCMU) nests were found during searches in rocky areas on the lower portion of southeastern PI ( 19:00-20:00), the SE spine and cliffs above mist-net site \#1 ( 01:00-02:00), and rocky outcrops on lower southeastern end (03:25-03:40). Cassin's Auklets (CAAU) were noted in all areas. SCMU were noted calling on the water just offshore. On 7 August, Pigeon Guillemot (PIGU) and CAAU nests, but no evidence of SCMU, were found during searches in 3 caves on the east side of the North Cliffs (09:59-10:35).

1996.-On 29 April, a CAAU carcass, 3 CAAU nests, and 1 Ashy Storm-Petrel (ASSP) nest were found during searches near a Barn Owl (BAOW) roost on southeastern PI.

1999.-One brooding adult was found in May 1999 (A. Hebshi unpublished data).

2007.- On 24 April, no evidence of SCMU was found during searches on the east side of PI.

2008.-An incubating adult SCMU was found in an artificial CAAU nest in June 2008; later that month the egg was found abandoned (J. Adams unpublished data).

2015.-On 16 April, 2 SCMU nests (1 brooding adult and 1 incubating adult) were found on the southwest shore, but none were found on the southeast shore.

\section{San Miguel Island, Hare Rock}

1994.-Evidence of SCMU was not noted on 11 April or 12 July, but 2 CAAU nests with incubating adults were found in April and a downy CAAU chick was found in July.

1995.-No evidence of SCMU was noted on 4 May.

2007.-No evidence of SCMU was noted on 23 April. ume 3. Principal Investigator's Reports, Part 3: Seabirds of the Southern California Bight, Book 2. Unpublished report, University of California, Irvine, CA. Pemberton, J.R. 1928. Additions to the known avifauna of the Santa Barbara Islands. Condor 30:144-148.

Sumner, E.L., AND R.M. Bond. 1939. An investigation of Santa Barbara, Anacapa, and San Miguel Islands, California. Unpublished manuscript, Channel Islands National Park, Ventura, CA.

\section{San Miguel Island, Nifty Rock}

2007.-No evidence of SCMU was noted on 23 April.

\section{San Miguel Island, Rhino Cave}

1994.-No evidence of SCMU was noted on 5 May or 12 July, but Rhinoceros Auklets (RHAU) flushed off the water near the cave in May, and an adult RHAU in incubating posture was observed in the cave in July (McChesney et al. 1995).

1995. - No evidence of SCMU was noted on 4 May, but 3 adult RHAU were observed in the cave.

2007. - No evidence of SCMU was noted on 23 April, 1 May, or 22 May, but PIGU eggshell fragments were seen on 1 May.

\section{San Miguel Island, East Harris Point}

1994.-No evidence of SCMU was noted on 12 July, but PIGU nests were seen.

2007.-On 1 May and 22 May, 2 abandoned SCMU eggs were observed in a shallow crevice.

\section{San Miguel Island, North Cuyler Harbor}

1996.-No evidence of SCMU was noted on 29 April, but the number of suitable nest sites was small. A BAOW was observed roosting in a cave littered with the remains of many CAAU.

\section{San Miguel Island, West Harris Point}

2007.-No evidence of SCMU was noted on 1 May.

\section{San Miguel Island, Hoffman Point}

2007.-On 24 April, a broken SCMU egg was found in a shallow crevice, but nothing was found on 2 May or 22 May.

2015.-No evidence of SCMU was noted during a brief visit on 16 April.

\section{San Miguel Island, Bay Point Sea Cave}

2007.-On 2 May, several broken SCMU eggs were found scattered in a crevice in a shoreline sea cave; a single broken SCMU egg was found in the same cave on 22 May. 